\title{
Evidence for host specificity of Theileria capreoli genotypes in cervids
}

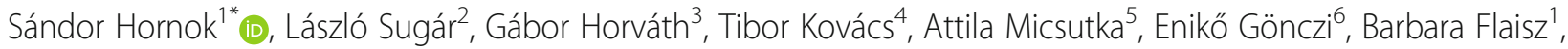 \\ Nóra Takács ${ }^{1}$, Róbert Farkas ${ }^{1}$, Marina L. Meli ${ }^{6}$ and Regina Hofmann-Lehmann ${ }^{6}$
}

\begin{abstract}
Data on the prevalence of piroplasms in buffaloes and large game animal species are lacking from several central European countries. Therefore, to investigate the presence of Babesia/Theileria DNA in these hosts, 239 blood and 270 spleen samples were taken from cervids (red, fallow, and roe deer), as well as from water buffaloes, mouflons, and wild boars in southwestern Hungary, followed by DNA extraction and molecular analysis for piroplasms. All samples from buffaloes and wild boars were PCR negative. Based on spleen samples, the prevalence of piroplasms was significantly higher in red deer (41.7\%) than in fallow deer (23.5\%). Two genotypes of Theileria capreoli were identified, which showed significant association with their host species (i.e. genotype "capreoli-CE1" was exclusively found in roe deer, whereas red and fallow deer harbored only genotype "elaphi-CE1"). Genotype "elaphi-CE1" of T. capreoli was also detected in one mouflon. No Babesia spp. were identified. In conclusion, in the evaluated region, genotypes of $T$. capreoli show host-associations among cervids, and at least one of these genotypes may infect mouflons.
\end{abstract}

Keywords: Buffalo, Red deer, Fallow deer, Roe deer, Wild boar, Cervus, Capreolus, Theileria

\section{Letter to the Editor}

In Europe, the estimated individual number of large game animal species, such as red deer (Cervus elaphus), roe deer (Capreolus capreolus), and wild boars (Sus scrofa) have been showing a steady increase during the past decades [1-3]. This also implies a tendency of growing the eco-epidemiological impact of relevant species. Apart from causative agents of infections that pose a threat only to cervids or wild boars, large game animals are also known to harbour pathogens that may affect domestic ungulates [4] or humans [5].

Ticks (Acari: Ixodidae) are regarded as the most important vectors (transmitters of pathogens) in the temperate zone [6]. Large game animal species are important hosts in the life-cycle of several tick species with high veterinary-medical significance, as exemplified by Ixodes ricinus [7] and Haemaphysalis concinna [8], thus influencing the dispersal and geographical distribution of relevant tick species [9].

\footnotetext{
* Correspondence: hornok.sandor@univet.hu

${ }^{1}$ Department of Parasitology and Zoology, University of Veterinary Medicine, Budapest, Hungary

Full list of author information is available at the end of the article
}

Piroplasms (Apicomplexa: Piroplasmida) are tickborne protozoa, infecting red and white blood cells of their vertebrate hosts [10]. Species, for which domestic and wild ungulates are susceptible, belong to Babesia (sensu stricto) and the genus Theileria [10], and in Europe, their most important tick vectors include I. ricinus and Haemaphysalis spp. [11, 12].

In Hungary, red deer and roe deer were shown to be important hosts of adults and immature stages of $I$. ricinus and $H$. concinna [13]. Also, several tick-borne pathogens have been reported from these tick species in the country, for which wild (game) animals are known to be reservoirs, including piroplasms [14]. However, relevant data, particularly molecular evidence on piroplasms infecting wild ungulates in Hungary are lacking.

Therefore, the aim of this study was to perform a molecular survey targeting piroplasms among water buffaloes (Bubalus bubalis) and individuals of five large game animal species: the red deer (Ce. elaphus), the fallow deer (Dama dama), the roe deer (Ca. capreolus), the mouflon (Ovis orientalis) and the wild boar (S. scrofa) in Hungary. The significance of these large game animal 
species is well illustrated by the fact that wild boars and cervids included in the present study occur in all countries of mainland Europe; mouflons are widespread in central and southern Europe; and the number of water buffalos living in Europe increased 1.5 times from 2000 to 2009 [4].

Samplings were performed between January 2013 and December 2014. In a natural reserve at Mórahalom $\left(46^{\circ} 13^{\prime} 4.5^{\prime \prime} \mathrm{N}, 19^{\circ} 53^{\prime} 1.3^{\prime \prime} \mathrm{E}\right)$, blood samples were drawn from the jugular vein of water buffalos into EDTA tubes. These animals are kept extensively, grazing on grasslands from spring to autumn (thus exposed to ticks).

In an approximately $3000 \mathrm{~km}^{2}$ region of south-western Hungary $\left(46^{\circ} 15^{\prime}-46^{\circ} 50^{\prime} \mathrm{N}, 17^{\circ}-17^{\circ} 50^{\prime} \mathrm{E}\right)$, blood or spleen samples were collected from game animals, depending on the time of death and conditions allowed by hunters. Blood samples were taken from the heart of fresh cadavers of game animals and transferred into EDTA tubes. If this was not possible, spleen sample was cut with sterile scalpel blade and put into plastic vial. Samples included in the study are shown in Table 1 (2nd, 3rd columns). All samples were frozen on the day of collection at $-20{ }^{\circ} \mathrm{C}$ until processing.

The DNA was extracted individually, from $200 \mu \mathrm{l}$ blood or $c .10 \mathrm{mg}$ of spleen with the QIAamp DNA Mini Kit (Qiagen, Hilden, Germany) according to the manufacturer's instructions, including extraction controls to monitor cross-contamination of samples. All DNA samples were screened for the presence of piroplasms by a conventional PCR [15], which amplifies an approximately 500 bp fragment of the $18 \mathrm{~S}$ rRNA gene of Babesial Theileria spp. with the primers BJ1 (forward: $5^{\prime}$-GTC TTG TAA TTG GAA TGA TGG-3') and BN2 (reverse: 5' ${ }^{\prime}$-TAG TTT ATG GTT AGG ACT ACG-3') as reported [16].

Each PCR was run with positive and negative controls (i.e. sequence-verified DNA of Babesia canis, and nontemplate reaction mixture, respectively). Negative controls and extraction controls remained PCR negative in all tests. Sanger-dideoxy sequencing was performed from all piroplasm PCR positive samples at Biomi Inc. (Gödöllő, Hungary). Only unambiguous sequences were considered further. Sequences were aligned and compared to reference GenBank sequences by nucleotide BLASTn program (https://blast.ncbi.nlm.nih.gov). Representative sequences were submitted to GenBank (accession number for T. capreoli genotype "capreoli-CE1": KY308178; for genotype "elaphi-CE1”: KY308179).

Exact confidence intervals (CI) for the prevalences were calculated at $95 \%$ level. Prevalences were compared between identical sample types (blood or spleen) by Fisher's exact test. Differences were regarded significant if $P<0.05$.

Altogether 118 samples were PCR positive for piroplasms. All blood samples of buffalos and blood/spleen samples of wild boars were PCR negative. Based on spleen samples (Table 1), the prevalence of piroplasms was significantly higher in red deer $(41.7 \%$, CI: $31.7-$ $52.2 \%)$ than in fallow deer (23.5\%, CI: $15-34 \%)$ $(P=0.01)$. The PCR products from 84 positive samples were successfully sequenced, and in these only two genotypes of $T$. capreoli were identified. These two genotypes (designated here as "capreoli-CE1" and "elaphi-CE1": Table 1) differed in one nucleotide (thymine vs adenine in position 681, respectively). Genotype "capreoli-CE1" was exclusively found in roe deer, whereas red and fallow deer harbored only genotype "elaphi-CE1" (Table 1). Thus, the occurrence of Theileria genotypes ("capreoli-CE1" vs "elaphi-CE1") was strongly associated with host species (roe deer vs red deer and fallow deer: $P<0.0001$ ).

In addition, genotype "elaphi-CE1" of $T$. capreoli was detected in one mouflon. No Babesia spp. were identified.

To the best of our knowledge, this is the first study in Europe, which demonstrated simultaneous and significant differences in the prevalences of $T$. capreoli genotypes among wild ruminant species in the same region. Here, genotype "capreoli CE1" was only found in roe deer, while genotype "elaphi CE1" was the only piroplasm detected in red deer and fallow deer. The observation that red and fallow deer share the same T. capreoli genotype, can be explained by the close taxonomic relationship of these ruminants (both in the Cervinae, but roe deer in the Capreolinae, see [17]). These results are

Table 1 Results of molecular analyses of blood and spleen DNA samples from water buffalos and large game animal species in Hungary

\begin{tabular}{|c|c|c|c|c|}
\hline \multirow[t]{2}{*}{ Species } & \multicolumn{2}{|c|}{ PCR positive/all tested samples (\%) } & \multicolumn{2}{|c|}{ No. of samples with Theileria capreoli genotype } \\
\hline & Blood & Spleen & capreoli CE1 & elaphi CE1 \\
\hline Water buffalo & $0 / 60$ & - & - & - \\
\hline Red deer & 20/48 (41.7\%) & 40/96 (41.7) & - & 33 \\
\hline Fallow deer & $8 / 33(24.2 \%)$ & 20/85 (23.5) & - & 20 \\
\hline Roe deer & 28/65 (43.1\%) & $1 / 6(16.7)$ & 27 & 3 \\
\hline Mouflon & $1 / 16(6.3 \%)$ & $0 / 4$ & - & 1 \\
\hline Wild boar & 0/17 & 0/79 & - & - \\
\hline
\end{tabular}


in line with previous observations on the prevalences of theileriae in individual cervid species from other countries, i.e. $T$. capreoli identical with genotype "capreoli-CE1" of the present study was detected in four roe deer in Germany (KU510437 in [18]); $T$. capreoli identical with isolate "elaphi-CE1" of the present study predominated in red deer in Poland (Theileria sp. ZS-T04: DQ520836, see [19]) and fallow deer in Italy (GU373972 and GU373975, see [20]). The likely vector candidate for T. capreoli in Hungary is $H$. concinna because both above genotypes were found in questing nymphs and adults of this tick species in the country [14]. Furthermore, red deer and roe deer were shown to be important hosts of adults and immature stages of $H$. concinna in the same region of Hungary [13].

Genotype "elaphi-CE1" of T. capreoli was also detected in a mouflon. This host species has not been reported to be susceptible to this piroplasm. For instance, in a recent comprehensive survey carried out in Germany on piroplasms of game animals, only Babesia spp. were identified in mouflons [18].

Interestingly, no Babesia spp. were identified among sequenced PCR products in the present study. This finding contrasts with the moderate to high prevalence of Babesia spp. infection in large game animal species in nearby countries (i.e. $62.8 \%$ in roe deer in Germany: [18]; $10.7 \%$ in wild ruminants in Switzerland: [21]; $12.6 \%$ in roe deer in Italy: [22]). This discrepancy is most likely related to the game animals sampled in this study, which might have been different from those in other countries in the context of risk factors (host species, age, and altitude), shown to influence the prevalence of Babesia spp. in wild ruminants [21]. It is also highly relevant to consider that tick-infestation of wild ungulates may vary significantly between countries even within central Europe. For example, on roe deer I. ricinus (the vector of several Babesia spp. in Europe: [23]) was reported to predominate in Germany (i.e. with $92.6 \%$ of all ticks, see [24]), whereas $H$. concinna (the most likely vector of $T$. capreoli) represented $90.9 \%$ of all ticks collected from roe deer in Hungary [13].

In summary, in the study area, $T$. capreoli has two genotypes, which appear to be associated with particular species of cervids, and at least one of these genotypes is also able to infect mouflons.

\section{Abbreviation}

CE: Central Europe

\section{Acknowledgements}

Molecular biology work was partially performed using the logistics of the Center for Clinical Studies at the Vetsuisse Faculty of the University of Zurich.

\section{Funding}

Molecular analyses were funded by OTKA 115854 (Hungary).

\section{Availability of data and materials}

The sequences obtained and analyzed during the current study are deposited in the GenBank database under the accession numbers KY308178 (T. capreoli genotype "capreoli-CE1") and KY308179 (genotype "elaphi-CE1"). All other relevant data are included in the article.

\section{Authors' contributions}

SH initiated and organized the study, wrote the manuscript. LS designed and performed most large game animal samplings. GH and TK significantly contributed to the samples. EG, BF and NT performed DNA extractions and molecular analyses. AM supervised part of the sample collection. RF and MLM conceived the parasitological and molecular analyses, respectively. RHL supervised the whole study. All authors read and approved the final manuscript.

\section{Ethics approval and consent to participate}

On location No. 1 of this study (Mórahalom), buffaloes were sampled for monitoring purposes during regular veterinary care by the veterinarian in charge of this herd (Dr Tibor Kovács, co-author of this study); therefore, no ethical approval was required. Local anesthesia (with 2\% lidocaine) was used to alleviate the pain of buffaloes during blood sampling. On location No. 2 of this study (south-western Hungary), game animals were shot by hunters while observing the relevant law (No. LV/1996, on the protection, management and hunting of game animals), in the course of organized hunting activity in the territory of SEFAG Forest Management and Wood Industry Share Co. (permission issued under number 153-1 for 2013/2014) according to the Somogy County Hunting Supervisory Authority. No further ethical approval was required because on this location no living animals were handled.

\section{Consent for publication}

Not applicable.

\section{Competing interests}

The authors declare that they have no competing interests.

\section{Publisher's Note}

Springer Nature remains neutral with regard to jurisdictional claims in published maps and institutional affiliations.

\section{Author details}

'Department of Parasitology and Zoology, University of Veterinary Medicine, Budapest, Hungary. ${ }^{2}$ Department of Game Management and Ethology, Faculty of Agricultural and Environmental Sciences, University of Kaposvár, Kaposvár, Hungary. ${ }^{3}$ Veterinary Authority, Csurgó, Hungary. ${ }^{4}$ Veterinary Authority, Mórahalom, Hungary. ${ }^{5}$ Food Chain Safety and Veterinary Authority, Pásztó, Hungary. ${ }^{6} \mathrm{Clinical}$ Laboratory and Center for Clinical Studies, Vetsuisse Faculty, University of Zurich, Zurich, Switzerland.

Received: 2 June 2017 Accepted: 25 September 2017

Published online: 10 October 2017

\section{References}

1. Burbaité L, Csányi S. Roe deer population and harvest changes in Europe. Estonian J Ecol. 2009:58:169-80.

2. Burbaité L, Csányi S. Red deer population and harvest changes in Europe. Acta Zool Lit. 2010;20:179-88.

3. Massei G, Kindberg J, Licoppe A, Gačić D, Šprem N, Kamler J, et al. Wild boar populations up, numbers of hunters down? A review of trends and implications for Europe. Pest Manag Sci. 2015;71:492-500.

4. Martin C, Pastoret PP, Brochier B, Humblet MF, Saegerman C. A survey of the transmission of infectious diseases/infections between wild and domestic ungulates in Europe. Vet Res. 2011;42:70.

5. Yabsley M, Shock B. Natural history of zoonotic Babesia: role of wildlife reservoirs. Int J Parasitol Parasites Wildl. 2013:2:18-31.

6. Jongejan F, Uilenberg G. The global importance of ticks. Parasitology. 2004; 129(Suppl):S3-S14.

7. Medlock JM, Hansford KM, Bormane A, Derdakova M, Estrada-Peña A, George JC, et al. Driving forces for changes in geographical distribution of Ixodes ricinus ticks in Europe. Parasit Vectors. 2013;6:1.

8. Nosek J. The ecology, bionomics and behaviour of Haemaphysalis (Haemaphysalis) concinna tick. Z Parasitenkd. 1971;36:233-41. 
9. Hornok S, Mulvihill M, Szőke K, Gönczi E, Sulyok KM, Gyuranecz M, Hofmann-Lehmann R. Impact of a freeway on the dispersal of ticks and Ixodes ricinus-borne pathogens: forested resting areas may become Lyme disease hotspots. Acta Vet Hung. 2017:65:242-52.

10. Schreeg ME, Marr HS, Tarigo JL, Cohn LA, Bird DM, Scholl EH, et al. Mitochondrial genome sequences and structures aid in the resolution of Piroplasmida phylogeny. PLoS One. 2016:11, e0165702.

11. Hunfeld KP, Hildebrandt A, Gray JS. Babesiosis: recent insights into an ancient disease. Int J Parasitol. 2008;38:1219-37.

12. Mans BJ, Pienaar R, Latif AA. A review of Theileria diagnostics and epidemiology. Int J Parasitol Parasites Wildl. 2015:4:104-18.

13. Hornok S, Horváth G, Jongejan F, Farkas R. Ixodid ticks on ruminants, with on-host initiated moulting (apolysis) of Ixodes, Haemaphysalis and Dermacentor larvae. Vet Parasitol. 2012;187:350-3.

14. Hornok S, Takács N, Kontschán J, György Z, Micsutka A, Iceton S, et al. Diversity of Haemaphysalis-associated piroplasms of ruminants in centraleastern Europe, Hungary. Parasit Vectors. 2015;8:627.

15. Casati S, Sager H, Gern L, Piffaretti JC. Presence of potentially pathogenic Babesia sp. for human in Ixodes ricinus in Switzerland. Ann Agric Environ Med. 2006:13:65-70.

16. Hornok S, Mester A, Takács N, Fernández de Mera IG, de la Fuente J, Farkas R. Re-emergence of bovine piroplasmosis in Hungary: has the etiological role of Babesia divergens been taken over by B. major and Theileria buffeli? Parasit Vectors. 2014:7:434

17. Fernández MH, Vrba ES. A complete estimate of the phylogenetic relationships in Ruminantia: a dated species-level supertree of the extant ruminants. Biol Rev. 2005;80:269-302.

18. Kauffmann M, Rehbein S, Hamel D, Lutz W, Heddergott M, Pfister K, Silaghi C. Anaplasma phagocytophilum and Babesia spp. in roe deer (Capreolus capreolus), fallow deer (Dama dama) and mouflon (Ovis musimon) in Germany. Mol Cell Probes. 2017;31:46-54

19. Sawczuk M, Maciejewska A, Skotarczak B. Identification and molecular characterization of Theileria sp. infecting red deer (Cervus elaphus) in northwestern Poland. Eur J Wildl Res. 2008;54:225-30.

20. Galuppi R, Aureli S, Bonoli C, Caffara M, Tampieri MP. Detection and molecular characterization of Theileria sp. in fallow deer (Dama dama) and ticks from an Italian natural preserve. Res Vet Sci. 2011:91:110-5.

21. Michel AO, Mathis A, Ryser-Degiorgis MP. Babesia spp. in European wild ruminant species: parasite diversity and risk factors for infection. Vet Res. 2014:45:65.

22. Zanet S, Trisciuoglio A, Bottero E, de Mera IG, Gortazar C, Carpignano MG, Ferroglio E. Piroplasmosis in wildlife: Babesia and Theileria affecting freeranging ungulates and carnivores in the Italian Alps. Parasit Vectors. 2014;7:70.

23. Andersson MO, Bergvall UA, Chirico J, Christensson M, Lindgren PE, Nordstrom J, Kjellander P. Molecular detection of Babesia capreoli and Babesia venatorum in wild Swedish roe deer, Capreolus capreolus. Parasit Vectors. 2016;9:221.

24. Vor $T$, Kiffner $C$, Hagadorn $P$, Niedrig $M$, Rühe F. Tick burden on European roe deer (Capreolus capreolus). Exp Appl Acarol. 2010;51:405-17.

\section{Submit your next manuscript to BioMed Central and we will help you at every step:}

- We accept pre-submission inquiries

- Our selector tool helps you to find the most relevant journal

- We provide round the clock customer support

- Convenient online submission

- Thorough peer review

- Inclusion in PubMed and all major indexing services

- Maximum visibility for your research

Submit your manuscript at www.biomedcentral.com/submit

) Biomed Central 